\author{
Maria Mocarz-Kleindienst \\ iD https://orcid.org/0000-0002-2205-5470 \\ Katolicki Uniwersytet Lubelski Jana Pawła II \\ Wydział Nauk Humanistycznych \\ Instytut Językoznawstwa \\ Katedra Translatoryki i Języków Słowiańskich \\ 20-950 Lublin, Aleje Racławickie 14 \\ e-mail: momar@kul.pl \\ https://doi.org/10.18778/8220-520-6.08
}

\title{
O PRAGMATYCE PRZEKŁADU ADRESATYWÓW \\ - NA PODSTAWIE POLSKIEJ WERSJI LEKTORSKIEJ I NAPISÓW W DRAMACIE NIEMIEOŚĆ ANDRIEJA ZWIAGINCEWA
}

\section{About pragmatics in translation of forms of address based on the Polish voice over and subtitles in Andrei Zvyagintsev's drama Loveless}

\section{О прагматике перевоАа обращений - на основании польской версии закаАрового перевода и субтитров Арамы Ненюбовь Анарея Звягинцева}

\begin{abstract}
Streszczenie
Punktem wyjścia w podjętych badaniach jest przekonanie, że częstotliwość użycia i jakość adresatywów w dialogach filmowych jest podporządkowana parametrom funkcjonalnym gatunku filmowego. Przeprowadzono jakościową i ilościową analizę sposobów przekazu nominalnych form adresatywnych w polskiej wersji lektorskiej i napisowej w dramacie Niemiłość A. Zwiagincewa. Badania jakościowe wykazały silną tendencję do transferu form osobowych $\mathrm{z}$ adaptacją morfologiczną $\mathrm{w}$ obu wersjach. Konfrontatywne badania ilościowe obu wersji polskich wykazały większą liczbę opuszczeń w wersji lektorskiej. Parametrem regulującym ilość opuszczeń jest przede wszystkim funkcja adresatywu, nie jest nim natomiast asymetria na poziomie systemów.
\end{abstract}




\section{Summary}

The research is rested on the thesis that the frequency of use and quality of form of address in film dialogues are subordinated to the functional parameters of the specific film genre. A qualitative and quantitative analysis was carried out of the methods of translating the nominal forms of address in the Polish voice over and subtitles Zvyagintsev's drama Loveless. Qualitative studies have shown high tendency to transfer personal forms with morphological adaptation in both versions. Comparative and quantitative research of both Polish translations has shown a higher number of omissions in the voice over. The factor regulating the number of omissions is primarily the function of the forms of address but not asymmetry in language systems.

\section{Резюме}

Отравной точкой проведенных исследований является тезис о том, что частота использования и качество обращений в кинодиалогах подчинены функциональным параметрам киножанра. Был проведен качественный и количественный анализ способов передачи номинативных обращений в польском закаАровом переводе и субтитрах в Араме Нелюбовь А. Звягинцева. Качественный анализ выявил сильную тенденцию к переносу мичных имен с морфологической аАаптацией в обеих переводных версиях. Сопоставительный количественный анализ обеих польских версий обнаружил бо́льшее количество опущений в закадровом переводе. На количество опущений вмияет функция обращения, не асимметрия языковых систем.

Słowa kluczowe: adresatyw, przekład filmowy, napisy, wersja lektorska.

Keywords: form of address, film translation, subtitles, voice over.

Кмючевые смова: обращение, киноперевоА, субтитры, закаАровый перевоА.

\section{Adresatywy - informacje wstępne}

Formy adresatywne (adresatywy) są językowymi wykładnikami bezpośredniego zwracania się do rozmówcy, a w konsekwencji - werbalnymi sygnałami lub wzmocnieniami interakcyjnego charakteru komunikacji. Ich funkcjonowanie zawsze jest uwarunkowane sytuacją komunikacyjną. Dla przykładu, forma mianownikowa imienia własnego Monika użyta w funkcji adresatywu w zdaniu Monika, co o tym sądzisz? przytoczona poza kontekstem traci status jednostki adresatywnej, stając się jednostką prymarnie nazywającą osobę. W literaturze przedmiotu (np. Szarkowska, 2007; Bączkowska, 2019) często przywołuje się dwudzielny podział adresatywów: 1) formy wokatywne, zwane także apelatywnymi, jako jednostki syntaktycznie niezintegrowane z pozostałą częścią wypowiedzi (Aniu, czy możesz mi pomóc?) oraz 2) formy czasownikowe $\mathrm{z}$ towarzyszącymi im często formami zaimkowymi (np. mbl / ty, вbl / wy). Obecność formy zaimka jest motywowana normą i uzusem języka. Obserwujemy stałą co do zasady obecność zaimka w języku rosyjskim (Ты можешь мне помочь?) oraz jego pominięcie w języku polskim 
(Czy możesz mi pomóc?). Eugeniusz Tomiczek proponuje trójdzielną klasyfikację $\mathrm{z}$ wykorzystaniem kryterium formalno-gramatycznego: 1) formy pronominalne (ty, wy i in.), 2) nominalne (imiona, nazwiska, formy tytularne) i 3) atrybutywne (zaimki dzierżawcze, przymiotniki stopniowalne) (Tomiczek, 1983, 24-25). Różnorodność formalna jednostek adresatywnych przekłada się na ich zróżnicowanie funkcjonalne: od funkcji fatycznej, poprzez przedstawieniową po afektywną, służącą wyrażaniu pozytywnych i negatywnych emocji. Adresatywy jako jednostki o mocy performatywnej wskazują na charakter relacji między uczestnikami komunikacji, zakres dystansu społecznego między nimi. Są istotnym komponentem tzw. honoryfikatywności, czyli „informacji o towarzysko-społecznej relacji między nadawcą i odbiorcą (adresatem wypowiedzi) oraz relacji między nadawcą a bohaterem wypowiedzi” języka (Huszcza, 2006, 47). Adresatywy tworzą system uwarunkowany kulturowo, podatny na zmiany społeczno-obyczajowe i polityczne, odzwierciedlający procesy komunikacji i modelujący jej jakość. To powoduje, że często stanowią one obiekt zainteresowań badaczy zajmujących się ich społecznymi uwarunkowaniami, obecnością i ewolucją w różnych formach dyskursu: medialnego, religijnego, politycznego, sportowego i in. (np. Kostro, Wróblewska-Pawlak, 2013; Fedoriuk, 2016; Chwesiuk, 2016), konfrontacją na poziomie systemów językowych (np. Tomiczek, 1983; Pytel-Pandey, 2003; Charciarek, 2014; Sosnowski, 2015). W refleksji przekładoznawczej, także tej o profilu filmowym, często akcentuje się trudności w ich przekazie, wynikające z ich silnego zakotwiczenia w kulturze i języku danego narodu oraz asymetrii systemów językowo-kulturowych uwikłanych w relacje oryginał - przekład (np. Đurović, 2014; Pavesi, 2012; Szarkowska, 2006; Bączkowska 2019; Paszkowska-Wilk, 2018).

\section{Funkcje adresatywów w dialogach filmowych}

Adresatywy jako konkretne realizacje wybranych elementów systemu ujawniają się na poziomie użycia języka w sytuacji bezpośredniego zwrotu nadawcy do obecnego przy nim adresata lub jego przywołania. Są zatem niejako zakotwiczone w strukturach dialogowych, rozumianych umownie, jako formy komunikacji zarówno między dwiema osobami, jak i z udziałem większej liczby uczestników. Dialogi jako podstawowa forma codziennej ustnej komunikacji są także zasadniczym konstruktem narracji filmowej, imitującej realny świat lub projektującej świat fantastyczny, bazującym na realnym doświadczeniu i praktykach komunikacji międzyludzkiej. Sarah Kozloff, przekonując o polifunkcjonalności materii dialogowej $\mathrm{w}$ filmach fabularnych, na potwierdzenie zasadności swojej tezy wymienia następujące funkcje dialogów relewantne dla rozwoju narracji: 1) kreowanie przestrzeni diagetycznej i zakotwiczanie $\mathrm{w}$ niej bohaterów (anchorage of the diagesis and characters), 2) informowanie o związkach przyczynowo-skutkowych scalających oś fabularną filmu (communication of narrative causality), 3) urzeczywistnianie zdarzeń 
fabularnych (enactment of narrative causality), 4) ujawnianie natury postaci (character revalation), 5) imitacja realnej rzeczywistości (adherence to the code of realism), 6) obserwacja emocji i ocen widzów (control of viewer evaluation and emotions) (Kozloff, 2000, 33). Formy adresatywne należą do tych komponentów struktury dialogowej filmów, które poprzez swój udział - w aspekcie ilościowym i jakościowym - wspomagają charakterystykę funkcjonalną filmowej narracji.

Punktem wyjścia w podjętych badaniach jest przekonanie, że częstotliwość użycia i jakość adresatywów w dialogach filmowych jest motywowana jakością komunikacji między postaciami. Ta zaś jest pochodną relacji rodzinnych, zawodowych oraz sytuacji życiowych, w jakich znaleźli się widoczni na ekranie bohaterowie. Zwroty adresatywne są językowymi markerami tych relacji. Jakość komunikacji słyszanej na ekranie jest podporządkowana jednocześnie parametrom zewnętrznym, tj. konwencjom gatunkowym produkcji filmowej. $\mathrm{Z}$ tą tezą powiązane jest założenie, że w różnych gatunkach filmowych mamy do czynienia $\mathrm{z}$ różną częstotliwością $\mathrm{i}$ jakością zastosowanych form adresatywnych. Potwierdzają to przeprowadzone wcześniejsze badania naukowe (np. Hołobut, Woźniak, 2017; Mocarz-Kleindienst, 2021). Zakres ich obecności jest motywowany pragmatycznie, ma bezpośredni związek z funkcjami w zachowaniach interakcyjnych między bohaterami filmowymi.

\section{Charakterystyka materiału badawczego}

Jako materiał badawczy posłużyły nominalne formy adresatywne, niezintegrowane składniowo, w rosyjskim dramacie rodzinnym Niemiłość (Нелюбовь) w reżyserii Andrieja Zwiagincewa (2017 r.) oraz w dwóch polskojęzycznych profesjonalnych przekładach: wersji lektorskiej autorstwa Haliny Osuch (emitowanej w AleKino +) oraz napisowej, opracowanej przez Piotra Kotowskiego (dostępnej na DVD). Film, wielokrotnie nominowany i nagradzany na międzynarodowych festiwalach filmowych, pokazuje dramat rodziny żyjącej na przedmieściach Moskwy. Skłóceni ze sobą małżonkowie - Żenia i Borys - są zajęci układaniem sobie życia z nowymi partnerami, bagatelizując potrzeby 12-letniego niechcianego syna Aloszy. Ten, podsłuchując wieczorem kłótnię rodziców, dowiaduje się, że żaden $\mathrm{z}$ nich nie chce po rozwodzie zająć się jego wychowaniem. Postanawia więc uciec z domu. Zrozpaczeni rodzice rozpoczynają dramatyczne poszukiwania. Angażują w tym celu służby poszukiwawcze, których działania nie przynoszą oczekiwanego rezultatu. Aloszy nie udaje się odnaleźć. Rozwiedzeni małżonkowie przeprowadzają się do swoich partnerów, jednak zmiana partnera nie pociąga za sobą zmian stylu ich życia. Ta pokrótce zarysowana fabuła pozwala odnieść analizowany film do gatunku dramatu rodzinnego z odpowiednio skonstruowaną strukturą, estetyką przekazu oraz zawartością tematyczną dialogów. W filmie przeważają dialogi z udziałem dwóch osób, często są to kłótnie, rozmowy pełne napięć (małżonków, także Żeni z matką), wyrzutów, następnie rozpaczy z powodu zaginięcia syna. 
Rozwodzący się małżonkowie nie zwracają się do siebie po imieniu. Borys wypowiada imię swojej żony zaledwie jeden raz, gdy spotykają się razem w prosektorium, aby ustalić, czy znalezione ciało kilkunastoletniego chłopca to ich syn. Znamienne jest, że imiona małżonków widz poznaje w scenach, gdy spotykają się oni ze swoimi nowymi partnerami lub prowadzą koleżeńskie rozmowy w miejscu pracy. Również imię chłopca wybrzmiewa nie w bezpośrednim kontakcie matki $\mathrm{z}$ dzieckiem, ale w sytuacji, gdy ta zrozpaczona dzwoni do męża z wiadomością, że ich syn zaginął. $Z$ racji prowadzonych akcji poszukiwawczych $w$ tok narracji wplecione są rozmowy grupy poszukiwawczej z rodzicami, kolegami i nauczycielami Aloszy. W bardziej łagodnej atmosferze przebiegają natomiast rozmowy głównych bohaterów: Żeni i Borysa z ich nowymi partnerami: Antonem i Maszą. W filmie odnotowano 41 wystąpień nominalnych form adresatywnych, w tym następujących po sobie powtórzeń w funkcji zawołań ( $w$ dwóch scenach: w pierwszej - 4, w kolejnej - 2 powtórzenia). Jest to stosunkowa niewielka liczba, zważywszy na czas trwania filmu (ponad 2 godz.). Zatem już sama niewysoka częstotliwość użyć sygnalizuje jakość relacji interpersonalnych bohaterów.

\section{Cele i metodologia badań}

Status ontologiczny form adresatywnych jako form konstytuowanych przez kontekst i sytuację komunikacyjną powoduje, że nie powinny one być badane jako niezależne autonomiczne jednostki systemów językowych, ale zawsze w powiązaniu z konkretną sytuacją ich użycia. Właśnie z uwagi na te okoliczności $\mathrm{w}$ niniejszym studium została przyjęta pragmatyczna perspektywa badawcza, zorientowana po pierwsze na aspekt funkcjonalny form adresatywnych, ściśle powiązany $\mathrm{z}$ osią fabularną gatunku filmowego, po drugie - na pragmatykę odbioru wersji tłumaczonych. W badaniach będą uwzględnione 2 układy relacji translatorskich: 1) wertykalny (pionowy) - z nadrzędną pozycją oryginału i wtórnymi wobec niego dwiema wersjami przekładu: napisową i lektorską oraz 2) horyzontalny (poziomy), skoncentrowany na paralelnych wersjach tłumaczonych, różniących się kanałem dotarcia do widza: ustnej wersji lektorskiej (jako izosemiotycznej w stosunku do również ustnej wersji oryginalnej) oraz pisemnej wersji napisowej (jako diasemiotycznej). Analiza pierwszego układu będzie mieć charakter jakościowy. W jej ramach - stosownie do zadeklarowanej pragmatycznej perspektywy badawczej - analizie poddane zostaną adresatywy pod kątem ich reprezentacji leksykalnych ze wskazaniem na funkcje komunikacyjne, jakie pełnią one w oryginale, podporządkowane narracji dramatu rodzinnego. Jednocześnie zostaną omówione sposoby ich przekazu w obu wersjach thumaczonych.

W układzie poziomym badanych obiektów skupię się na analizie ilościowej translatów obecnych w obu wersjach. Przesłanką przemawiającą za zasadnością przeprowadzenia analizy ilościowej jest utrwalony w literaturze przedmiotu 
(np. Tomaszkiewicz, 2006) pogląd, że obie techniki wykazują tendencje do skracania informacji: jej kondensacji i pomijania (opuszczeń na poziomie dialogów). Wyraźnie silniejszą tendencję wykazuje wersja napisowa - wskutek zmiany kanału i wynikających z niej ograniczeń technicznych (maksymalnie 2 wersy na ekranie) oraz możliwości percepcyjnych widzów. Nie negując praktyki opuszczeń stosowanych przez thumaczy w obu wersjach, w niniejszym studium postaram się wykazać, po pierwsze, $\mathrm{w}$ jakim stopniu mechanizm opuszczeń dotyczy samych adresatywów, po drugie, czy faktycznie w wersji napisowej odnotowujemy więcej przypadków rezygnacji w przekazu form adresatywnych, po trzecie, czy w przypadku stwierdzenia symetrycznych opuszczeń w obu wersjach wpływ na nie mają takie parametry, jak np. asymetria na poziomie systemów w zakresie obecności w nich samych jednostek mogących pełnić funkcję adresatywu, czy może raczej odmienny uzus komunikacyjny, wyznaczający reguły zastosowania i frekwencji użycia danej jednostki leksykalnej w funkcji adresatywnej odrębnie w każdym języku.

\section{Prezentacja i omówienie wyników badań}

\subsection{Analiza jakościowa}

W tabeli 1 zaprezentowane zostaną poszczególne typy jednostek leksykalnych pełniących szczegółowe funkcje pragmatyczne w filmie Niemiłość. Przy każdej pozycji, oprócz informacji na temat leksykalnego sposobu wyrażenia adresatywów, podana jest zwięzła charakterystyka funkcjonalna danego typu, poparta stosownymi przykładami.

Tabela 1

\begin{tabular}{|c|c|c|c|c|}
\hline Lp. & $\begin{array}{l}\text { Typ leksykalno- } \\
\text {-funkcjonalny }\end{array}$ & Wersja rosyjska & $\begin{array}{c}\text { Polska wersja } \\
\text { lektorska }\end{array}$ & Napisy polskie \\
\hline I. & $\begin{array}{l}\text { Imię w funkcji } \\
\text { zawolania }\end{array}$ & 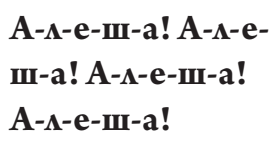 & ------ & Alosza! \\
\hline \multirow[t]{2}{*}{ II. } & \multirow{2}{*}{$\begin{array}{l}\text { Imię jako zwrot } \\
\text { grzecznościowy } \\
\text { do członka ro- } \\
\text { dziny (mąż-żona } \\
\text { (II.1), matka-cór- } \\
\text { ka II.2) }\end{array}$} & $\begin{array}{l}\text { II.1: - Я вам } \\
\text { русским языком } \\
\text { говорю: это не } \\
\text { он! - Жень! }\end{array}$ & $\begin{array}{l}\text { II.1: Wyraźnie } \\
\text { mówię, że to nie } \\
\text { on! - Żeniu! }\end{array}$ & $\begin{array}{l}\text { II.1: Ile mam po- } \\
\text { wtarzać?! To nie } \\
\text { on! - Żenia! }\end{array}$ \\
\hline & & $\begin{array}{l}\text { II.2: Маша, ты } \\
\text { же сама видишь, } \\
\text { зАесь все на голо- } \\
\text { вах Аруг на Аругу. }\end{array}$ & $\begin{array}{l}\text { II.2: Sama wi- } \\
\text { dzisz, że siedzimy } \\
\text { sobie na głowach. }\end{array}$ & $\begin{array}{l}\text { II.2. Masza, sama } \\
\text { widzisz, wszyscy } \\
\text { siedzimy tu sobie } \\
\text { na głowach. }\end{array}$ \\
\hline
\end{tabular}




\begin{tabular}{|c|c|c|c|c|}
\hline Lp. & $\begin{array}{l}\text { Typ leksykalno- } \\
\text {-funkcjonalny }\end{array}$ & Wersja rosyjska & $\begin{array}{c}\text { Polska wersja } \\
\text { lektorska }\end{array}$ & Napisy polskie \\
\hline \multirow[t]{4}{*}{ III. } & \multirow{4}{*}{$\begin{array}{l}\text { Imię jako zwrot } \\
\text { grzecznościowy } \\
\text { do partnera życio- } \\
\text { wego }\end{array}$} & $\begin{array}{l}\text { III.1: Жень, вста- } \\
\text { вай! Пора ехать. }\end{array}$ & $\begin{array}{l}\text { III.1: Żeniu, wsta- } \\
\text { waj! Czas jechać. }\end{array}$ & $\begin{array}{l}\text { III.1: Żenia, } \\
\text { wstawaj! }\end{array}$ \\
\hline & & III.2: Жень... & III.2: Żeniu! & III.2: Żenia! \\
\hline & & III.3: Борь... & III.3: Boria... & III.3: Borys... \\
\hline & & $\begin{array}{l}\text { III.4: Что ты, } \\
\text { Маш! Ты же } \\
\text { с ума сошиа! } \\
\text { Откуда такие } \\
\text { мысли? }\end{array}$ & $\begin{array}{l}\text { III.4: No co ty, } \\
\text { Maszo! Zwario- } \\
\text { wałaś... Skąd } \\
\text { takie myśli? }\end{array}$ & $\begin{array}{l}\text { III.4: Masza... } \\
\text { zwariowałaś? Co } \\
\text { ci przyszło do } \\
\text { głowy? }\end{array}$ \\
\hline \multirow[t]{3}{*}{ IV. } & \multirow{3}{*}{$\begin{array}{l}\text { Imię jako zwrot } \\
\text { do kolegów } \\
\text { w pracy (zawoła- } \\
\text { nie, nawiązanie } \\
\text { rozmowy, wyraz } \\
\text { zniecierpliwienia) }\end{array}$} & $\begin{array}{l}\text { IV.1: Женечка, } \\
\text { приди, пожалуй- } \\
\text { ста! }\end{array}$ & $\begin{array}{l}\text { IV.1: Żeniu, } \\
\text { zejdź, proszę! }\end{array}$ & $\begin{array}{l}\text { IV.1: Żenia, mo- } \\
\text { żesz zejść? }\end{array}$ \\
\hline & & $\begin{array}{l}\text { IV.2: Ааша, } \\
\text { короче... }\end{array}$ & $\begin{array}{l}\text { IV.2: Dasza, } \\
\text { słuchaj... }\end{array}$ & IV.2: Posłuchaj... \\
\hline & & $\begin{array}{l}\text { IV.3: Знаю же, } \\
\text { Сереж! }\end{array}$ & $\begin{array}{l}\text { IV.3: Znam to, } \\
\text { Sierioża! }\end{array}$ & $\begin{array}{l}\text { IV.3: Już to słysza- } \\
\text { łem! }\end{array}$ \\
\hline \multirow[t]{2}{*}{ V. } & \multirow{2}{*}{$\begin{array}{l}\text { Imię jako zwrot } \\
\text { do osób w spra- } \\
\text { wach służbowych }\end{array}$} & V.1: Антон... & $\begin{array}{l}\text { V.1: Panie Anto- } \\
\text { nie... }\end{array}$ & V.1: Anton... \\
\hline & & $\begin{array}{l}\text { V.2: - Aмıо! - } \\
\text { Иван? }\end{array}$ & $\begin{array}{l}\text { V.2: - Słucham! - } \\
\text { Iwan? }\end{array}$ & V.2: Iwan? \\
\hline VI. & $\begin{array}{l}\text { Nazwisko jako } \\
\text { sygnał wywarcia } \\
\text { presji }\end{array}$ & $\begin{array}{l}\text { Слушай, Кузне- } \\
\text { цов! }\end{array}$ & $\begin{array}{l}\text { Słuchaj, Kuznie- } \\
\text { cow! }\end{array}$ & Posłuchaj! \\
\hline \multirow[t]{4}{*}{ VII. } & \multirow{4}{*}{$\begin{array}{l}\text { Nazwy członków } \\
\text { rodziny w funkcji } \\
\text { zwrotu grzeczno- } \\
\text { ściowego (VII.1), } \\
\text { wyrażenia } \\
\text { pouczenia (VII.3, } \\
\text { VII.4), oburzenia } \\
\text { (VII.2, VII.6) }\end{array}$} & $\begin{array}{l}\text { VII.1: ЗАрав- } \\
\text { ствуй, пап! }\end{array}$ & $\begin{array}{l}\text { VII.1: Cześć, } \\
\text { tato! }\end{array}$ & $\begin{array}{l}\text { VII.1: Cześć, } \\
\text { tato! }\end{array}$ \\
\hline & & $\begin{array}{l}\text { VII.2: Ну, мам! } \\
\text { VII.3: ОАумайся, } \\
\text { Аочка, одумайся! }\end{array}$ & $\begin{array}{l}\text { VII.2: Mamo! } \\
\text { VII.3: Opamiętaj } \\
\text { się! }\end{array}$ & $\begin{array}{l}\text { VII.2: Mamo! } \\
\text { VII.3: Opamiętaj } \\
\text { się! }\end{array}$ \\
\hline & & $\begin{array}{l}\text { VII.4: А я тебе } \\
\text { сказала: при- } \\
\text { ползнешь, Ао- } \\
\text { ченька, ко мне, } \\
\text { приползнешь! }\end{array}$ & $\begin{array}{l}\text { VII.4: Mówiłam, } \\
\text { jeszcze do mnie } \\
\text { przyleziesz, ale } \\
\text { będzie za późno! }\end{array}$ & $\begin{array}{l}\text { VII.4: Powiedzia- } \\
\text { łam, że wrócisz do } \\
\text { mnie na kolanach. }\end{array}$ \\
\hline & & $\begin{array}{l}\text { VII.6: Мам, что } \\
\text { ты несешь? }\end{array}$ & $\begin{array}{l}\text { VII.6: Co ty } \\
\text { wygadujesz przy } \\
\text { obcych? }\end{array}$ & $\begin{array}{l}\text { VII.6: Mamo, po } \\
\text { co robisz scenę? }\end{array}$ \\
\hline
\end{tabular}


Tabela 1 (cd.)

\begin{tabular}{|c|c|c|c|c|}
\hline Lp. & $\begin{array}{l}\text { Typ leksykalno- } \\
\text {-funkcjonalny }\end{array}$ & Wersja rosyjska & $\begin{array}{c}\text { Polska wersja } \\
\text { lektorska }\end{array}$ & Napisy polskie \\
\hline \multirow[t]{2}{*}{ VIII. } & \multirow[t]{2}{*}{$\begin{array}{l}\text { Nazwy członków } \\
\text { rodziny } \\
\text { w funkcji zawo- } \\
\text { lania }\end{array}$} & $\begin{array}{l}\text { VIII.1: Мама! } \\
\text { Мам, открой! } \\
\text { Это я! Мама! } \\
\text { Мам, открой! } \\
\text { Алеша пропал! } \\
\text { Мам! }\end{array}$ & $\begin{array}{l}\text { VIII.1: Mamo, } \\
\text { otwórz! To ja! } \\
\text { Mamo, otwórz! } \\
\text { Alosza zaginął! }\end{array}$ & $\begin{array}{l}\text { VIII.1: Mamo! } \\
\text { Mamo, otwórz! } \\
\text { To ja! Mamo! } \\
\text { Mamo, otwórz! } \\
\text { Alosza zaginął! }\end{array}$ \\
\hline & & VIII.2: Ma-мa!! & VIII.2: ---- & VIII.2: Mamo!! \\
\hline IX. & $\begin{array}{l}\text { Nazwy członków } \\
\text { rodziny jako } \\
\text { zwroty do obcych } \\
\text { w celu wzbudze- } \\
\text { nia zaufania }\end{array}$ & $\begin{array}{l}\text { Понимаешь, } \\
\text { брат, мы все-рав- } \\
\text { но найдем, но, } \\
\text { может быть, } \\
\text { поздно. }\end{array}$ & $\begin{array}{l}\text { My i tak ją znaj- } \\
\text { dziemy, ale wtedy } \\
\text { może być za } \\
\text { późno. }\end{array}$ & $\begin{array}{l}\text { I tak dowiemy } \\
\text { się, wcześniej czy } \\
\text { później. }\end{array}$ \\
\hline \multirow[t]{3}{*}{$\mathbf{X}$. } & \multirow{3}{*}{\begin{tabular}{|l|} 
Nazwy osób jako \\
zwroty do niezna- \\
jomych: a) kon- \\
tekst zawodowy \\
- przekonanie \\
(IX.1), prośba \\
(IX.2); b) kon- \\
tekst prywatny \\
- nawiązanie \\
kontaktu (IX.3)
\end{tabular}} & $\begin{array}{l}\text { IX.1: Аевушка, } \\
\text { я вам рисую ре- } \\
\text { альную картину. }\end{array}$ & $\begin{array}{l}\text { IX.1: Mówię pani } \\
\text { jak jest. }\end{array}$ & $\begin{array}{l}\text { IX.1: Właśnie } \\
\text { mówię pani, jak } \\
\text { to naprawdę } \\
\text { wygląda. }\end{array}$ \\
\hline & & $\begin{array}{l}\text { IX.2: Момодой } \\
\text { чемовек! }\end{array}$ & $\begin{array}{l}\text { IX.2: Proszę } \\
\text { pana! }\end{array}$ & $\begin{array}{l}\text { IX.2: Młody } \\
\text { człowieku! }\end{array}$ \\
\hline & & $\begin{array}{l}\text { IX.3: Аевушка! } \\
\text { Можно? Я хотел } \\
\text { записать ваш } \\
\text { номер. }\end{array}$ & $\begin{array}{l}\text { IX.3: Da mi pani } \\
\text { swój numer tele- } \\
\text { fonu? }\end{array}$ & $\begin{array}{l}\text { IX.3: Cześć! } \\
\text { Mogę prosić o nu- } \\
\text { mer telefonu? }\end{array}$ \\
\hline \multirow[t]{2}{*}{ XI. } & \multirow[t]{2}{*}{$\begin{array}{l}\text { Nazwy osób jako } \\
\text { zwroty do grupy } \\
\text { rówieśniczej }\end{array}$} & $\begin{array}{l}\text { Х.1: Пацаны! } \\
\text { ПодожАите } \\
\text { меня! }\end{array}$ & $\begin{array}{l}\text { X.1: Chłopaki, } \\
\text { zaczekajcie! }\end{array}$ & $\begin{array}{l}\text { X.1: Chłopaki, } \\
\text { zaczekajcie! }\end{array}$ \\
\hline & & $\begin{array}{l}\text { Х.2: Аевчон- } \\
\text { ки, Аавайте за } \\
\text { мюбовь! }\end{array}$ & $\begin{array}{l}\text { X.2: Dziewczy- } \\
\text { ny, wypijmy za } \\
\text { miłość! }\end{array}$ & $\begin{array}{l}\text { X.2: Dziewczy- } \\
\text { ny, wypijmy za } \\
\text { miłość! }\end{array}$ \\
\hline XII. & $\begin{array}{l}\text { Substantywizmy } \\
\text { wyrażające emo- } \\
\text { cjonalny stosunek } \\
\text { do bliskich }\end{array}$ & $\begin{array}{l}\text { XI.1: Аюбимый, } \\
\text { я соскучилась за } \\
\text { тобой! } \\
\text { XI.2: 3Аравствуй, } \\
\text { моя родная! }\end{array}$ & $\begin{array}{l}\text { XI.1: Kochanie, } \\
\text { tęsknię za tobą! } \\
\text { XI.2: Cześć, ko- } \\
\text { chanie! }\end{array}$ & $\begin{array}{l}\text { XI.1: Stęskniłam } \\
\text { się za tobą, ko- } \\
\text { chany! } \\
\text { XI.2: Cześć, } \\
\text { skarbie! }\end{array}$ \\
\hline
\end{tabular}

Źródło: opracowanie własne. 
Z powyższego zestawienia wynika, że wśród jednostek leksykalnych zdolnych pełnić funkcje adresatywów wyraźnie dominują typowe dla tej roli imiona własne (formy deminutywne). W obu wersjach polskich mamy do czynienia $\mathrm{z}$ transferem rosyjskich nazw osobowych (poza przykładami III.3 i V.1) z towarzyszącą im adaptacją morfologiczną. Taki sposób przekazu zachowuje w przekładzie informację o narodowej identyfikacji bohaterów, zakotwicza ich w konkretnej przestrzeni kulturowo-językowej: ilość użytych imion rosyjskich (oraz 1 nazwisko) wyraźnie wskazuje, że akcja rozgrywa się w Rosji. W wyniku zastosowanej adaptacji polskie leksemy żeńskie otrzymują końcówki wołacza (jako przypadku typowego dla wyrażania funkcji adresatywnej danej nazwy) lub mianownika (jako jego zamiennika), który w opinii R. Huszczy wzmacnia potoczny rejestr wypowiedzi (Huszcza, 2006, 107). W wersji oryginalnej tę potoczność sygnalizują redukcje samogłosek wygłosowych (np. Mau). Porównanie dwóch wersji tłumaczonych daje możliwość obserwacji preferencji tłumaczy w zakresie użycia form wariantywnych (Żeniu / Żenia, Maszo / Masza). Tłumaczka w wersji lektorskiej najczęściej używa form wołacza, tłumacz w napisach zaś - wyłącznie mianownika. W przypadku wersji z użyciem formy wołacza sygnały potocznego stylu wypowiedzi są zlokalizowane w sytuacji pozajęzykowej, także na poziomie składni wypowiedzi. Stosowany konsekwentnie przez tłumaczy transfer imion jest podyktowany specyficzną sytuacją funkcjonowania obu wersji przekładu $\mathrm{w}$ filmie ze słyszalną w nim wersją oryginalną. Niezależnie od stopnia jej słyszalności - w celu zachowania efektu podobieństwa brzmienia imienia w oryginale i przekładzie jako warunku tożsamości osoby noszącej dane imię - zaproponowane polskie odpowiedniki mają bardzo podobnie brzmiące formy.

Stosunkowo często w charakterze adresatywów pojawiają się także nazwy członków rodziny. Ich obecność uzasadnia fabuła analizowanego dramatu rodzinnego. Generalnie obie wersje polskie otrzymują naturalne, podobnie brzmiące odpowiedniki w sytuacjach, gdy dana nazwa, użyta w funkcji zwrotu adresatywnego, zachowuje swoją podstawową referencję, czyli wskazuje na pokrewieństwo między nadawcą a adresatem kierowanej wypowiedzi. Obserwujemy symetryczność zastosowanych odpowiedników polskich w sytuacji zwrotu młodszego członka rodziny do starszego (córki / syna do matki: VIII.1, VII.2; córki do ojca: VII.1). W sytuacji odwrotnej, czyli zwrotu matki do córki takiej symetrii brakuje w obu wersjach, co wyraźnie wskazuje na różnice w zakresie użycia danego adresatywu w polskiej i rosyjskiej praktyce komunikacyjnej. Nie jest to przejaw asymetrii między językami. Na poziomie systemów bowiem odnotowujemy parę odpowiedników: doчka-córka, różne są jednak ich zakresy funkcjonowania. Polskie formy adresatywne córko, córeczko mają jednak nieco odmienny potencjał stylistyczny (nacechowanie pozytywne, a nawet wzniosłe). Zatem formalny brak odpowiednika jest uzasadniony pragmatycznie: wypowiedź brzmi naturalnie bez użycia wzmocnień adresatywnych. Funkcję kompensuje obraz zachowującej się nerwowo matki oraz wzburzony ton jej wypowiedzi, której celem jest poniżenie 
córki w obecności męża i wolontariuszki zaangażowanej w akcję poszukiwawczą Aloszy. Dialogi filmowe rejestrują także praktykę rosyjską używania nazw członków rodziny i nazw ogólnych osobowych (wskazujących na płeć, wiek, także pokrewieństwo) w oderwaniu od ich podstawowych znaczeń - w funkcji zwrotów do nieznajomych pełniących najczęściej funkcję fatyczną. Wersje polskie (przykłady IX.1, IX.3) nie rejestrują funkcjonalnych odpowiedników niezintegrowanych składniowo rosyjskich zwrotów adresatywnych. Są w nich natomiast użyte inne formy, np. zintegrowany składniowo leksem pani, pełniący funkcję nawiązania kontaktu. Ciekawym rozwiązaniem jest przykład IX.3, w którym funkcję fatyczną przejmuje formuła grzecznościowa cześć!.

\subsection{Porównawcza analiza ilościowa: wersja lektorska i napisowa}

Tabela 2

\begin{tabular}{|c|c|c|c|c|}
\hline \multirow[b]{2}{*}{ Lp. } & \multirow[b]{2}{*}{$\begin{array}{l}\text { Leksykalno-funkcjonalny } \\
\text { typ adresatywu }\end{array}$} & \multirow[b]{2}{*}{$\begin{array}{c}\text { Liczba użyć } \\
\text { w wersji } \\
\text { oryginalnej }\end{array}$} & \multicolumn{2}{|c|}{ Liczba opuszczeń } \\
\hline & & & $\begin{array}{c}\text { wersja } \\
\text { lektorska }\end{array}$ & $\begin{array}{l}\text { wersja } \\
\text { napiso- } \\
\text { wa }\end{array}$ \\
\hline I. & Imię w funkcji zawołania & 6 & 6 & 5 \\
\hline II. & $\begin{array}{l}\text { Imię jako zwrot grzecznościowy do człon- } \\
\text { ka rodziny }\end{array}$ & 4 & 1 & 0 \\
\hline III. & $\begin{array}{l}\text { Imię jako zwrot grzecznościowy do part- } \\
\text { nera życiowego }\end{array}$ & 5 & 0 & 0 \\
\hline IV. & Imię jako zwrot do kolegów w pracy & 3 & 0 & 2 \\
\hline V. & $\begin{array}{l}\text { Imię jako zwrot do osób w sprawach } \\
\text { służbowych }\end{array}$ & 2 & 0 & 0 \\
\hline VI. & Nazwisko jako sygnał wywarcia presji & 1 & 1 & 0 \\
\hline VII. & $\begin{array}{l}\text { Nazwy członków rodziny w komunikacji } \\
\text { rodzinnej }\end{array}$ & 6 & 4 & 3 \\
\hline VIII. & Nazwy członków rodziny jako zawołania & 6 & 4 & 1 \\
\hline IX. & $\begin{array}{l}\text { Nazwy członków rodziny jako zwroty do } \\
\text { obcych }\end{array}$ & 1 & 1 & 1 \\
\hline $\mathbf{X}$. & Nazwy osób jako zwroty do nieznajomych & 3 & 2 & 2 \\
\hline XI. & $\begin{array}{l}\text { Nazwy osób jako zwroty do grupy rówie- } \\
\text { śniczej }\end{array}$ & 2 & 0 & 0 \\
\hline XII. & $\begin{array}{l}\text { Substantywizmy, wyrażające emocjonalny } \\
\text { stosunek do bliskich }\end{array}$ & 2 & 0 & 0 \\
\hline
\end{tabular}

Źródło: opracowanie własne. 
$\mathrm{Na} 41$ wystąpień adresatywów w dialogach oryginalnych odnotowano 19 opuszczeń $\mathrm{w}$ wersji lektorskiej oraz $14 \mathrm{w}$ wersji napisowej. Zatem teza o tendencji do bardziej znacznego skracania treści wersji napisowej poprzez redukcję właśnie zwrotów adresatywnych nie została w badanym materiale potwierdzona. Jeżeli przyjrzeć się opuszczeniom w obu wersjach, to okaże się, że nie wynikają one z konieczności kondensacji tekstu pod wpływem ograniczeń czasowych lub przestrzennych. Najczęściej bowiem mamy z nimi do czynienia w przypadku użycia adresatywów w funkcji powtarzających się zawołań, nieuwikłanych w ciągi rozbudowanych wypowiedzi. Potwierdzają to dane w tabeli: najwyższy wskaźnik opuszczeń cechuje grupę I oraz VIII. Stosunkowo wysoki wskaźnik opuszczeń w stosunku do użyć w oryginale zanotowano także w grupie VII, w której wystąpiły powtórzenia, choć tym razem jako jednostki pokrewieństwa w komunikacji między członkami rodziny (мaм / mamo). Redukcję tych powtórzeń obserwujemy zarówno w wersji lektorskiej, jak i napisowej. Podobny w obu wersjach efekt redukcji, dający obraz względnej symetrii podejmowanych działań przez tłumaczy, w ww. przykładach jest motywowany zgoła odmiennymi przesłankami. Nie są nimi bowiem ograniczenia czasowo-przestrzenne, lecz podobieństwa brzmieniowe rosyjskich i polskich leksemów użytych w funkcji zawołań jednostek (np. A^еша!). Bardzo zbliżony fonetycznie polski wariant rosyjskiego imienia sprawia, że rezygnacja $\mathrm{z}$ jego przekazu $\mathrm{w}$ wersji lektorskiej i jego symboliczne jednostkowe użycie w napisie (przypuszczalnie po to, aby zapewnić stałą obecność napisów na ekranie) nie powoduje ubytków informacyjnych oraz zakłóceń percepcji słuchowej. Te ostatnie mogłyby wystąpić wskutek ewentualnego nakładania się jednostek bardzo podobnych brzmieniowo w dwóch izosemiotycznych wersjach: oryginalnej i lektorskiej. Zgodnie z postulatem Marka Hendrykowskiego (Hendrykowski, 2018, 90) nie następuje powtórna transmisja brzmień obniżająca jakość odbioru informacji słyszanych w dialogach. Z symetrią opuszczeń w obu wersjach mamy do czynienia także w przykładach: IX oraz X. Są one skutkiem odmiennego uzusu komunikacyjnego w języku rosyjskim i polskim, nieprzewidującego użycia leksemów: бpam, девуuкa jako zwrotów do nieznajomych w sytuacji braku partnerskich relacji między interlokutorami (przykład IX) czy zwrotów do nieznajomych w celu nawiązania znajomości (przykład X). Propozycje thumaczy brzmią naturalnie.

Dane z tabeli wskazują na jeszcze jedną prawidłowość. Najmniejszy udział opuszczeń w obu wersjach odnotowano w przypadku przekazu adresatywów wyrażonych imionami własnymi, pełniących funkcję identyfikującą bohaterów, markerów grzeczności językowej, relacji interpersonalnych (wyjątek: zawołania). Nieznacznie więcej w odniesieniu do nazw członków rodziny, z uwagi na poszerzoną o kontekst pozarodzinny możliwość ich użycia w języku rosyjskim jako zwrotów do osób niespokrewnionych. Największy udział opuszczeń zaobserwować można w przypadku nazw pospolitych nazywających osoby. Mają one zdolność rozszerzania swoich zakresów znaczeniowych odrębnie w każdym 
z języków (nawet tak pokrewnych, jak język polski i rosyjski). Skutkuje to różnicami w ich funkcjonalnym użyciu, odnotowanymi także w filmie Niemiłość (przykłady IX oraz X девуuка, брат).

\section{Podsumowanie}

Celem podjętych badań była analiza jakości i zakresu przekazu (mierzonego liczbą użyć i opuszczeń) form adresatywnych w dramacie filmowym, z uwzględnieniem parametrów funkcjonalnych. Badania jakościowe wykazały silną tendencję do transferu form osobowych $\mathrm{z}$ adaptacją morfologiczną $\mathrm{w}$ obu wersjach. Badania ilościowe z kolei pokazały, że formy adresatywne wyrażone za pomocą imion własnych bardzo rzadko podlegają opuszczeniom. Tę sytuację można wytłumaczyć statusem funkcjonalnym tej grupy leksykalnej, identyfikującej bohaterów, wskazującej na relacje między nimi (zwłaszcza użycia form deminutywnych). Rozwiązania w zakresie przekazu imion własnych zaproponowane przez każdego z tłumaczy mają związek ze stosunkowo niską częstotliwością ich użycia w samych dialogach oryginalnych. Ta zaś, jak było wspomniane na początku, wynika z przyjętej przez A. Zwiagincewa koncepcji narracyjnej dramatu rodzinnego. Inne rozwiązania zastosowali tlumacze w stosunku do imion użytych w funkcji zawołań: w obu wersjach zaobserwowano wyraźną tendencję do opuszczeń. W tym przypadku zadecydowała pragmatyka odbioru: dla jednostek bardzo podobnie brzmiących w obu językach nie ma potrzeby ich dublowania w przekładzie. Badania porównawcze wykazały większą liczbę opuszczeń w wersji lektorskiej. Ma to związek z dążeniem do unikania brzmieniowych dubletów, zwłaszcza gdy oryginalny adresatyw jest użyty jako jednostka autonomiczna, powtarzająca się $\mathrm{w}$ formule zawołania. Nieliczne przypadki asymetrii zastosowanych opuszczeń w porównywanych wersjach są rezultatem pojedynczych decyzji tłumaczy w odniesieniu np. do postaci trzecioplanowych (kolegów z pracy). Parametrem regulującym ilość opuszczeń jest przede wszystkim funkcja adresatywu, nie jest nim natomiast asymetria na poziomie systemów.

\section{Bibliografia}

Bączkowska, A. (2019). Apelatywne formy adresatywne w polskim nieprofesjonalnym thumaczeniu komedii romantycznej "What Women Want”. Rocznik Przekładoznawczy, 14. 43-72. http://dx.doi.org/10.12775/RP 2019.002

Charciarek, A. (2014). Tendencje rozwojowe we współczesnym polskim i czeskim systemie adresatywnym. W: Kultura komunikacji językowej 3. Kultura języka w komunikacji zawodowej (7-22). A. Piotrowicz, M. Witaszek-Samborska, K. Skibski (red.). Poznań: Wyd. Poznańskiego Towarzystwa Przyjaciół Nauk.

Chwesiuk, U. (2016). Formy adresatywne w mediach społecznościowych. Kwartalnik Językoznawczy, 2, 28-23. 
Đurović, A. (2014). Das Anredesystem im Deutschen und in den serbischen Untertiteln des Films „Das Leben der anderen”. In: Translation und Transkulturelle Kommunikation (85-203). A. Đurović, V. Kučiš (eds.). Beograd: Univerzitet u Beogradu.

Fedoriuk, M. (2015). Formy adresatywne w ustnej komunikacji religijnej-aspekt empiryczno-porównawczy (na materiale wspótczesnego języka polskiego i ukraińskiego). Annales Universitatis Paedagogicae Cracoviensis, Studia Linguistica, X, 40-56.

Hendrykowski, M. (2018). Drugie spojrzenie. Analizy i interpretacje. Poznań: Wyd. Naukowe Uniwersytetu im. Adama Mickiewicza.

Hołobut, A., Woźniak, M. (2018). Historia na ekranie. Gatunek filmowy a przekład audiowizualny. Kraków: Wyd. Uniwersytetu Jagiellońskiego.

Huszcza, R. (2006). Honoryfikatywność. Gramatyka. Pragmatyka. Typologia. Warszawa: Wyd. Naukowe PWN.

Kostro, M., Wróblewska-Pawlak, K. (2013). Formy adresatywne jako środek jawnej i ukrytej deprecjacji kobiet polityków w polskim dyskursie polityczno-medialnym. Tekst i dyskurs - text und diskurs, 6, 105-120.

Kozloff, S. (2000). Overhearing Film Dialogue. Barkeley: University of California Press.

Mocarz-Kleindienst, M. (2021). O praktyce opuszczeń w polskiej wersji lektorskiej filmów rosyjskojęzycznych. Acta Polono-Ruthenica (155-168). http://dx.doi.org/10.31648/ apr.6438.

Paszkowska-Wilk, A. (2018). Polskie formy adresatywne $w$ rosyjskich przekładach filmowych. W: Jednostki języka w systemie i tekście (153-161). A. Charciarek, A. Zych, E. Kapela (red.). Katowice: Wyd. Uniwersytetu Śląskiego.

Pavesi, M. (2012). The enriching functions of adress shifts in film translation. In: AVT and Media Accessibility at the Crossroads. Media for All 3. (335-356). A. Remael, P. Orero, M. Caroll (eds.). Amsterdam-New York: Rodopi.

Pytel-Pandey, D. (2003). System adresatywny wspótczesnego języka niemieckiego i rosyjskiego. Konfrontacja socjolingwistyczna. Wrocław: Oficyna Wydawnicza ATUT.

Sosnowski, W. (2015). Formy adresatywne. Aspekt językowy i socjologiczny. Semantyka a konfrontacja językowa, 5 (319-332). D. Roszko, J. Satoła-Staskowiak (red.). Warszawa: Slawistyczny Ośrodek Wydawniczy.

Szarkowska, A. (2006). Formy adresatywne w przekładzie z języka polskiego na polski. Rocznik Przekładoznawczy, 2, 211-221.

Szarkowska, A. (2007). Formy apelatywne we wspótczesnym języku polskim. W: Język polski XXI wieku: analizy, oceny, perspektywy (229-236). G. Szpila (red.). Kraków: Tertium.

Tomaszkiewicz, T. (2006). Przektad audiowizualny. Warszawa: Wyd. Naukowe PWN.

Tomiczek, E. (1983). System adresatywny współczesnego języka polskiego i niemieckiego. Socjolingwistyczne studium konfrontatywne. Wrocław: Wyd. Uniwersytetu Wrocławskiego. 